\title{
33. EVIDENCE FOR DISSOLUTION AND SORTING OF PLANKTONIC FORAMINIFERS IN PLEISTOCENE SEDIMENTS AT HOLE 708A ${ }^{1}$
}

\author{
G. Vilks ${ }^{2}$ and D. Buckley ${ }^{2}$
}

\begin{abstract}
Pleistocene and Pliocene sediments from the top five cores of Hole 708A, western Indian Ocean, were subsampled to compare the degree of carbonate dissolution in pelagic and turbidite sediments. The extent of dissolution for each sample was established using the percent of whole planktonic tests and an index based on the dominance of planktonic genera resistant to dissolution. Most samples show evidence for dissolution; foraminifers are significantly more dissolved in pelagic sediments than turbidites. Sorting of sediment is evident in those samples where the percentages of whole juvenile tests are high, but adult tests are low.
\end{abstract}

\section{INTRODUCTION}

Berger (1970) established a ranking for planktonic foraminifers from plankton tows and surface sediments according to their susceptibility to dissolution (Table 1 from Berger, 1970). Berger (1970) ranks 22 species, with species 1 as the most susceptible to dissolution and species 22 as the least susceptible. Berger's ranking was established by an experiment conducted in the water column with present-day faunas of the Pacific Ocean.

Hole 708A was drilled in an abyssal plain between the Madingley Rise and Seychelles Bank in $4096.5 \mathrm{~m}$ of water (Fig. 1). The drill penetrated $236.2 \mathrm{~m}$ of sediment and recovered $189.7 \mathrm{~m}$ of core that ranges down into the lower Oligocene material (Shipboard Scientific Party, 1988). The depth of this site is such that it is at times exposed to lysoclinal as well as carbonate compensation depth (CCD) environments.

The sediments consist of turbidites (up to $36 \%$ by volume) interbedded with pelagic oozes of mainly nannofossil clays and radiolarians. The turbidite layers consist mainly of fragments or whole tests of planktonic foraminifers (Shipboard Scientific Party, 1988).

The purpose of this study was to relate the rate of carbonate dissolution to diagenesis driven by organic oxidation. However, because of uncertainties during sampling and laboratory analyses, we interpret only the paleontological results of the investigation.

We used the species rank numbers of Berger (1970) to establish dissolution indexes for each of the most common planktonic genera present at Hole 708A. The generic dissolution indexes (Table 2) avoids some of the uncertainties concerning the presence of extinct species downcore.

\section{METHODS}

Turbidites and pelagic sediments were differentiated on the basis of sediment color and other such visual indicators as graded bedding. The darker shades were assumed to indicate pelagic sediments, with white or pale colors indicative of possible turbidites. The white or pale sediments seem to be coarser because of the presence of planktonic tests. Both turbidites and pelagic

\footnotetext{
${ }^{1}$ Duncan, R. A., Backman, J., Peterson, L. C., et al., 1990. Proc. ODP, Sci. Results, 115: College Station, TX (Ocean Drilling Program).

2 Atlantic Geoscience Centre, Geological Survey of Canada, Bedford Institute of Oceanography, Dartmouth, Nova Scotia, Canada, B2Y 4A2.
}

\begin{tabular}{|c|c|}
\hline Rank & Species \\
\hline 1 & Globigerinoides ruber \\
\hline 2 & Orbulina universa \\
\hline 3 & Globigerinella siphonifera \\
\hline 4 & Globigerina rubescens \\
\hline 5 & Globigerinoides sacculifer \\
\hline 6 & Globigerinoides tenellus \\
\hline 7 & Globigerinoides conglobatus \\
\hline 8 & Globigerina bulloides \\
\hline 9 & Globigerina quinqueloba \\
\hline 10 & Globigerinita glutinata \\
\hline 11 & Candeina nitida \\
\hline 12 & Globorotalia hirsuta \\
\hline 13 & Globorotalia truncatulinoides \\
\hline 14 & Globorotalia inflata \\
\hline 15 & Globorotalia cultrata \\
\hline 16 & Neogloboquadrina dutertrei \\
\hline 17 & Neogloboquadrina pachyderma \\
\hline 18 & Pullenia obliquiloculata \\
\hline 19 & Globorotalia crassaformis \\
\hline 20 & Sphaeroidinella dehiscens \\
\hline 21 & Globorotalia tumida \\
\hline
\end{tabular}

Note: Data after Berger (1970).

sediments were subsampled on the basis of these shipboard observations.

The percent of whole tests of planktonic foraminifers from the total number of particles was determined in sample fractions coarser than $0.063 \mathrm{~mm}$ (Table 3 ). Tests were counted in whole samples (smallest count $=96$ specimens) or in sample splits when the number was large (largest calculated number $=$ 32,768 ). Undamaged specimens were considered as whole tests. Foraminifers were identified to the generic level in samples coarser than $0.250 \mathrm{~mm}$. In a number of samples, whole tests were not present in the fraction coarser than $0.250 \mathrm{~mm}$, but they were found in high percentages in the fractions between 0.063 and $0.250 \mathrm{~mm}$ (Samples 115-708A-1H-2, 20-25 cm, 115-708A-2H-5, $73-75 \mathrm{~cm}$, and 115-708A-13X-5, 41-43 cm).

The dissolution index for each sample was calculated by averaging the product of ratios of each genus identified in the coarse fraction of the sample and the generic dissolution index:

$$
\Sigma_{i=1, N}=C_{i} / C_{T} \times I_{G} / N,
$$




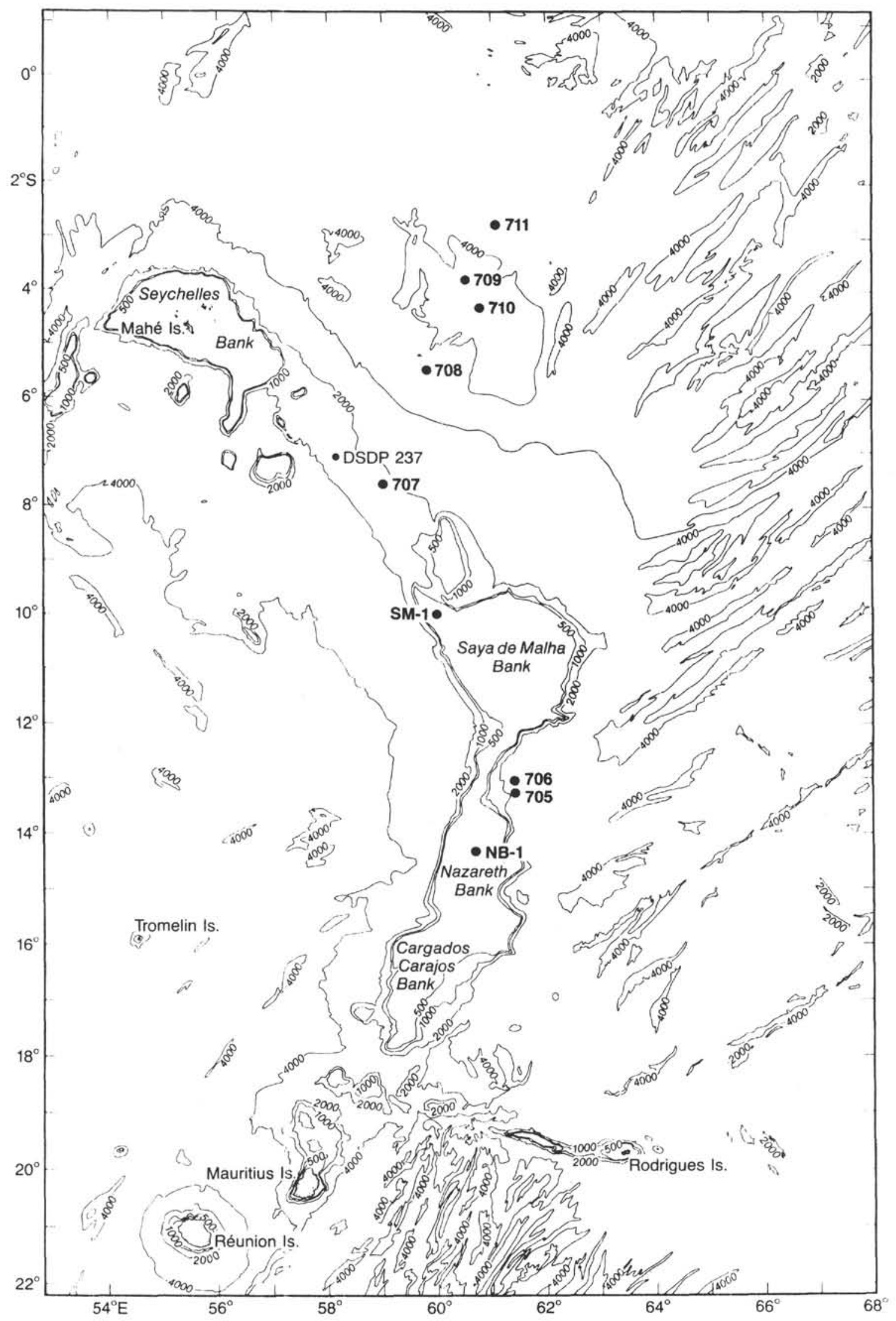

Figure 1. Location of Site 708 and major features of bathymetry (from Shipboard Scientific Party, 1988). 
Table 2. Generic dissolution indexes, Hole 708A.

\begin{tabular}{llc}
\hline \multicolumn{1}{c}{ Genus } & \multicolumn{1}{c}{$\begin{array}{c}\text { Species } \\
\text { indexes }\end{array}$} & $\begin{array}{c}\text { Generic } \\
\text { index }\end{array}$ \\
\hline Globigerinoides & $1,5,6,7$ & 4.8 \\
Orbulina & 2 & 2.0 \\
Globigerinella & 3 & 3.0 \\
Globigerina & $4,8,9$ & 7.0 \\
Globigerinita & 10 & 10.0 \\
Candeina & 11 & 11.0 \\
Globorotalia & $12,13,14,15,19,21$ & 15.7 \\
Neogloboquadrina & 16,17 & 16.5 \\
Pulleniatina & 18 & 18.0 \\
Sphaeroidinella & 20 & 20.0 \\
\hline
\end{tabular}

Note: Generic indexes are the averages of species dissolution indexes from Berger (1970).

where

$C_{i}=$ the number of specimens in a sample belonging to genus $i$,

$C_{T}=$ the total specimen count in a sample,

$I_{G}=$ the generic dissolution index, and

$N=$ the total number of genera.

The higher values of dissolution indexes are indicative of greater dissolution than the low values.

Sediment size analysis was carried out with a Model TA II Coulter counter using 30 - and $200-\mu \mathrm{m}$ apertures.

\section{RESULTS}

The dissolution indexes calculated on the basis of the percentages of the resistant genera range between 16 and 5 (Table 3). Samples with " 0 " values did not contain specimens larger than $0.250 \mathrm{~mm}$. Furthermore, because these samples contained large percentages of whole small tests that were difficult to identify, the " 0 " values were disregarded in the comparison of preservation between turbidites and pelagic sediments. Exclusive of the " 0 " values, the mean dissolution value within turbidites was 10.17 , and that of pelagic sediments was 13.59. The difference is significant on $99.99 \%$ confidence level, according to a t-test. Thus, the dissolution indexes would suggest that on the average, the carbonates in the pelagic sediments are more dissolved than in turbidites.

The percent whole tests in a sample range between $4 \%$ and $71 \%$ (Table 3). The mean value of percent whole tests within turbidites is $37.9 \%$ and within pelagic sediments, $24.45 \%$. The difference is significant between $99.9 \%$ and $99.0 \%$ probability levels. The percent whole tests would also suggest that carbonates have been more dissolved in the pelagic sediments. The rate of dissolution determined by the dissolution indexes and the percent whole tests correlates well in the pelagic sediments (Fig. 2), but poorly in the turbidites (Fig. 3).

On the average, the turbidites are coarser than the pelagic sediments (Table 4). There is considerably more sand and silt in the turbidites, but because of the large variability of the sand fraction, only the mean silt percent is significantly larger.

\section{DISCUSSION}

Significant correlation between the percent whole tests and dissolution index in pelagic sediments suggest that only such insitu processes as the dissolution of tests has modified the assemblage of species (Fig. 2). The large scatter of points in the turbidite samples (Fig. 3) reflect multiple sources of sediment and sorting during transport. In an area of turbidite activity, size sorting of tests is possible and may culminate in an extreme condition where only juveniles are present. An example of pronounced sorting is seen in Sample 115-708A-2H-5, 73-75 cm, where $61 \%$ of whole tests were present in the $0.063-0.250-\mathrm{mm}$ size fraction.

In the pelagic setting, the extent of dissolution is partly dependent on the production of planktonic tests; therefore, samples with high percentages of whole tests and low dissolution indexes may represent periods of higher productivity in the surface waters (See Fig. 3).

The dominance of genera resistant to dissolution suggest that carbonate dissolution has taken place in the majority of samples, except for a few discrete layers in the Pleistocene turbidites. The assemblages in these layers are representative of colder conditions than reflected by the present-day equatorial assemblages of Boltovskoy (1969). In Sample 115-708A-2H-4, 44-46 cm, the dissolution index is low because of the unusually high numbers of Orbulina, a genus which is not common in equatorial waters. In the sample intervals between $115-708 \mathrm{~A}-3 \mathrm{H}-4,44 \mathrm{~cm}$, and $115-708 \mathrm{~A}-3 \mathrm{H}-5,47 \mathrm{~cm}$, the low indexes are a result of the unusually high presence of Orbulina, Globigerinella, Globigerina, and Globigerinita. Globigerina is represented with G. bulloides and $G$. quinqueloba, which are cold-temperate species (Boltovskoy, 1969). It is unlikely that these colder water planktonic foraminifers have been introduced as a result of turbidite action and their presence is indicative of enhanced preservation caused by faster burial in the turbidite environment.

We have noted that the percentage of organic carbon is uniformly low in all of the samples that we tested. Only five samples in the Pleistocene sediments exceeded $0.1 \%$ organic carbon, with the maximum reaching $0.14 \%$. This result indicates that either very little organic carbon reached the seafloor at the site, or that oxidation of all of the sediments took place at or near the seafloor. There was no consistent difference between the pelagic type sediments and the turbidite intervals.

\section{CONCLUSIONS}

The assemblage of planktonic foraminifers in most of the samples show evidence of dissolution, with an average rate of dissolution significantly less in turbidites than in pelagic sediments. A discrete layer of well-preserved tests at about $1.6 \mathrm{~m} . \mathrm{y}$. contains a distinct colder water assemblage compared with older and younger sediments. In some samples, the low numbers or absence of whole planktonic tests in the size fraction greater than $0.250 \mathrm{~mm}$ but their presence between 0.063 and $0.250 \mathrm{~mm}$ suggests sediment sorting.

\section{ACKNOWLEDGMENTS}

This is Geological Survey of Canada Contribution No. 22689.

\section{REFERENCES}

Berger, W. H., 1970. Planktonic foraminifera: selective solution and the lysocline. Mar. Geol., 8:111-138.

Boltovskoy, E., 1969. Living planktonic foraminifera at the $90^{\circ}$ meridian from the equator to the Antarctic. Micropaleontology, 15(2): 237-265, Pls. 1-3.

Shipboard Scientific Party, 1988. Site 708. In Backman, J., Duncan, R. A., et al., Proc. ODP, Init. Repts., 115: College Station, TX (Ocean Drilling Program).

Date of initial receipt: 12 July 1989

Date of acceptance: 20 December 1989

Ms 115B-177 
Table 3. Counts of planktonic foraminifers, generic dissolution indexes, sample dissolution indexes, and percent of whole tests in samples from Hole 708A.

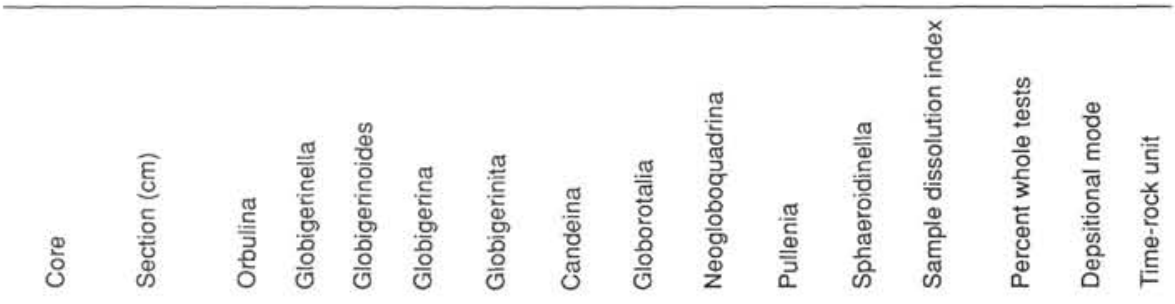

$\begin{array}{llllllllllllll}2.0 & 3.0 & 4.8 & 7.0 & 10.0 & 11.0 & 15.7 & 16.5 & 18.0 & 20.0\end{array}$

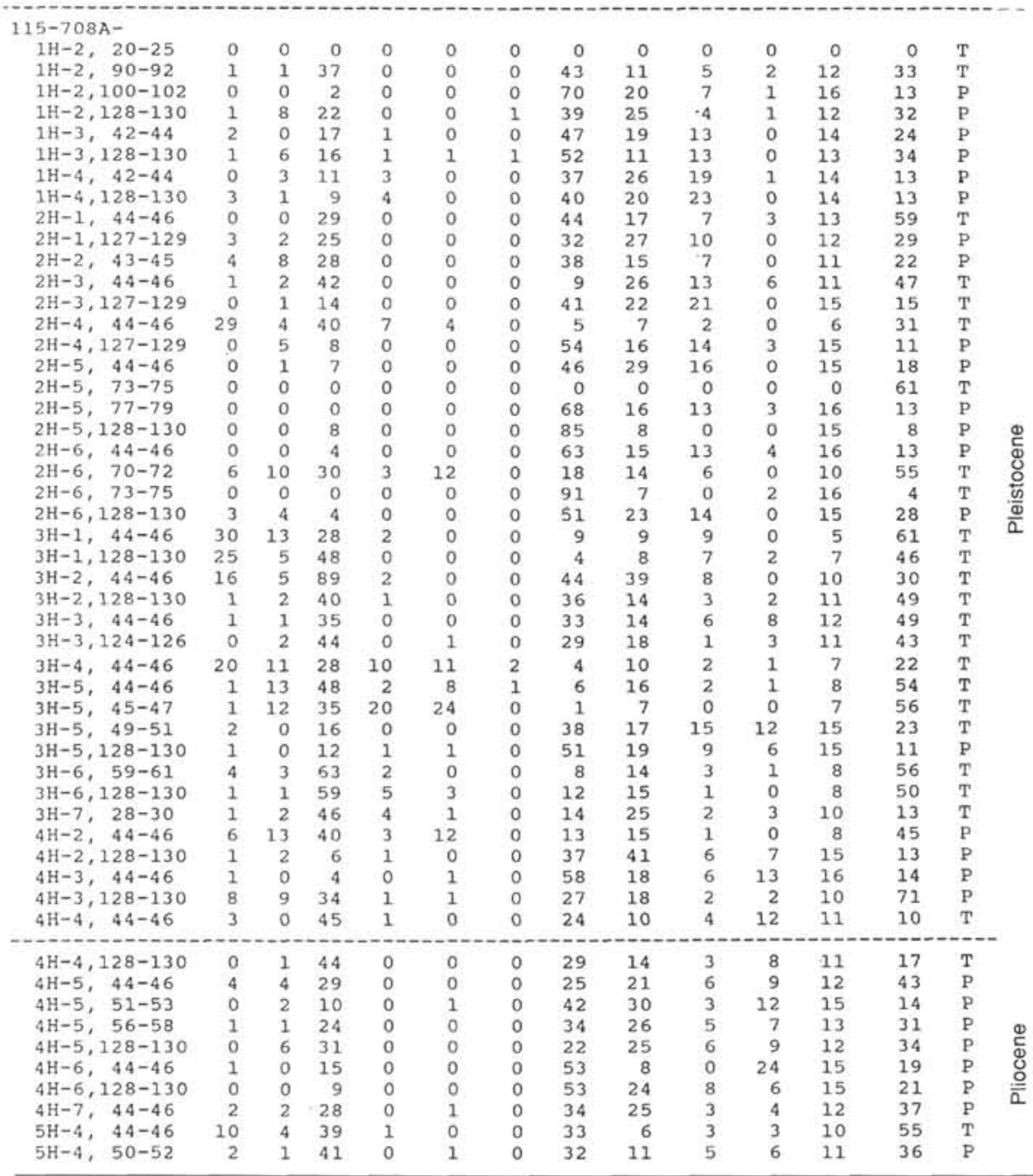

Note: Depositional modes are $\mathrm{P}=$ pelagic and $\mathrm{T}=$ turbidite. 


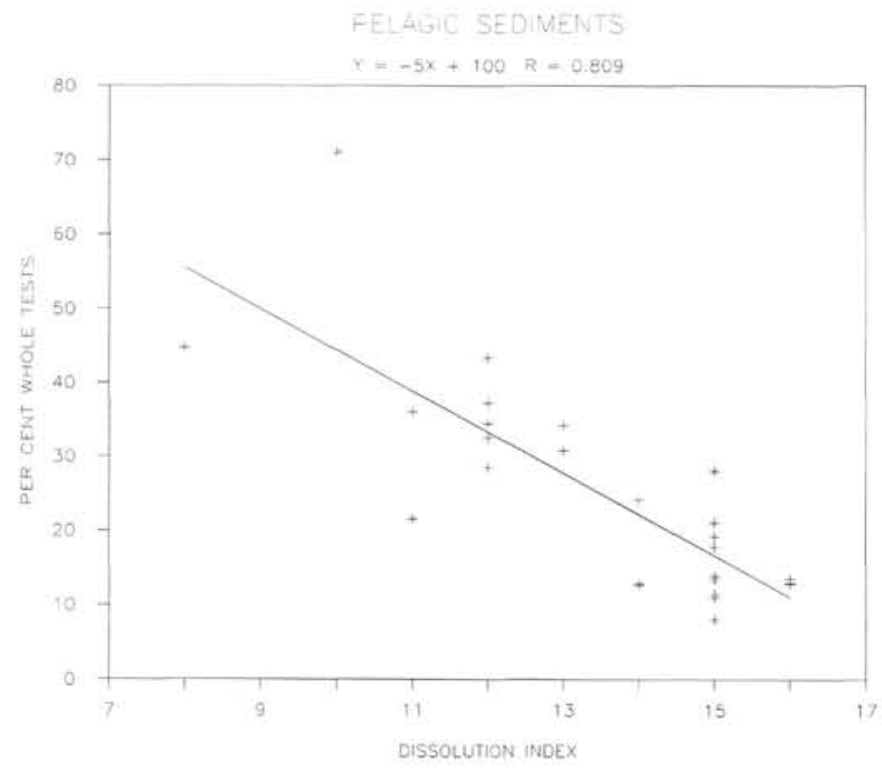

Figure 2. Dissolution index (see text for definition) related to percent of whole planktonic tests in pelagic sediments.

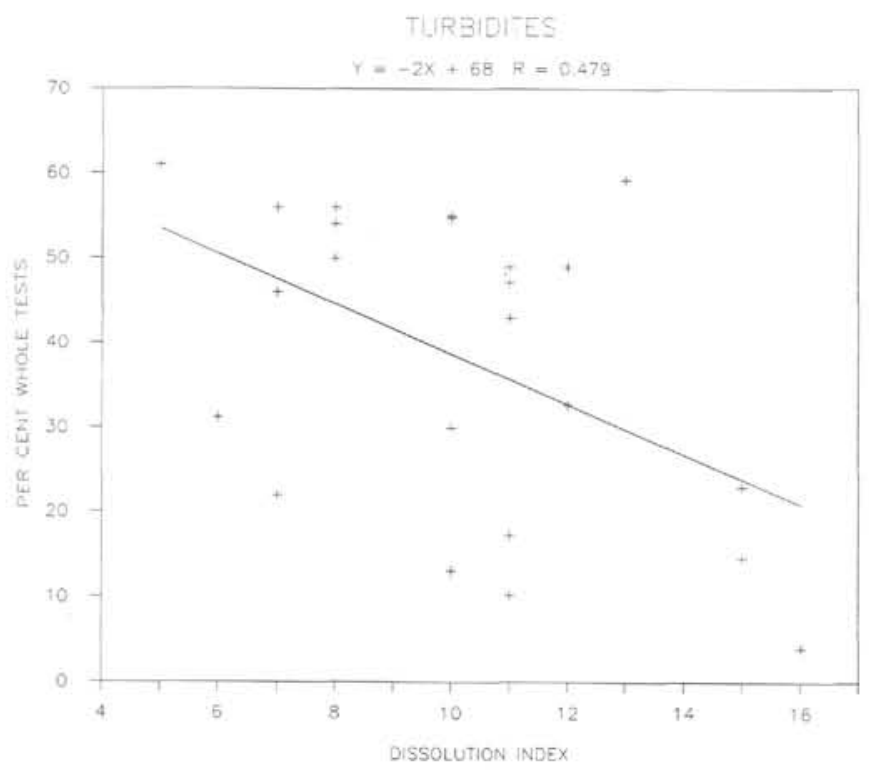

Figure 3. Dissolution index (see text for definition) related to percent of whole planktonic tests in turbidite sediments.
Table 4. Percent sand, silt, clay, and kurtosis of sediments, Hole 708A.

\begin{tabular}{|c|c|c|c|c|c|}
\hline $\begin{array}{l}\text { Core, section } \\
\text { interval }(\mathrm{cm})\end{array}$ & $\begin{array}{l}\text { Sand } \\
(\%)\end{array}$ & $\begin{array}{l}\text { Silt } \\
(\%)\end{array}$ & $\begin{array}{l}\text { Clay } \\
(\%)\end{array}$ & Kurtosis & $\begin{array}{l}\text { Depositional } \\
\text { mode }\end{array}$ \\
\hline $1 \mathrm{H}-2,20-25$ & 0.00 & 39.89 & 60.11 & 2.10 & T \\
\hline $1 \mathrm{H}-2,90-92$ & 1.39 & 66.64 & 31.97 & 2.17 & $\mathrm{~T}$ \\
\hline $1 \mathrm{H}-2,100-102$ & 0.60 & 58.17 & 41.23 & 2.13 & $\mathbf{P}$ \\
\hline $1 \mathrm{H}-2,128-130$ & 0.00 & 36.93 & 63.07 & 2.11 & P \\
\hline $1 \mathrm{H}-3,42-44$ & 0.00 & 36.03 & 63.97 & 2.05 & P \\
\hline $1 \mathrm{H}-3,128-130$ & 0.00 & 40.19 & 59.81 & 2.10 & P \\
\hline $1 \mathrm{H}-4,42-44$ & 0.30 & 60.91 & 38.79 & 2.04 & $\mathbf{P}$ \\
\hline $1 \mathrm{H}-4,128-130$ & 0.48 & 58.27 & 41.24 & 2.08 & P \\
\hline $2 \mathrm{H}-1,44-46$ & 0.24 & 51.82 & 47.93 & 2.11 & $\mathrm{~T}$ \\
\hline $2 \mathrm{H}-1,127-129$ & 0.00 & 39.71 & 60.29 & 1.99 & P \\
\hline $2 \mathrm{H}-2,43-45$ & 0.24 & 57.77 & 41.99 & 2.04 & $\mathrm{P}$ \\
\hline $2 \mathrm{H}-3,44-46$ & 6.84 & 65.87 & 27.29 & 1.99 & $\mathrm{~T}$ \\
\hline $2 \mathrm{H}-3,127-129$ & 0.66 & 56.58 & 42.76 & 2.20 & $\mathrm{~T}$ \\
\hline $2 \mathrm{H}-4,44-46$ & 0.30 & 85.39 & 14.31 & 3.49 & $\mathrm{~T}$ \\
\hline $2 \mathrm{H}-4,127-129$ & 0.00 & 33.02 & 66.98 & 2.12 & P \\
\hline $2 \mathrm{H}-5,44-46$ & 0.42 & 53.46 & 46.12 & 2.17 & P \\
\hline $2 \mathrm{H}-5,73-75$ & 0.36 & 70.87 & 28.77 & 1.94 & $\mathrm{~T}$ \\
\hline $2 \mathrm{H}-5,77-79$ & 0.24 & 57.79 & 41.97 & 2.06 & P \\
\hline $2 \mathrm{H}-5,128-130$ & 0.00 & 44.67 & 55.33 & 2.01 & $\mathbf{P}$ \\
\hline $2 \mathrm{H}-6,44-46$ & 0.60 & 60.93 & 38.47 & 2.09 & P \\
\hline $2 \mathrm{H}-6,70-72$ & 0.00 & 71.69 & 28.51 & 2.08 & $\mathrm{~T}$ \\
\hline $2 \mathrm{H}-6,73-75$ & 0.24 & 59.33 & 40.43 & 2.03 & $\mathrm{~T}$ \\
\hline $2 \mathrm{H}-6,128-130$ & 0.18 & 62.01 & 37.81 & 2.25 & P \\
\hline $3 \mathrm{H}-1,44-46$ & 0.24 & 83.18 & 16.58 & 3.03 & T \\
\hline $3 \mathrm{H}-1,128-130$ & 0.24 & 84.30 & 15.45 & 3.03 & T \\
\hline $3 \mathrm{H}-2,44-46$ & 4.94 & 69.74 & 25.31 & 1.95 & $T$ \\
\hline $3 \mathrm{H}-2,128-130$ & 0.85 & 76.42 & 22.74 & 2.40 & T \\
\hline $3 \mathrm{H}-3,44-46$ & 0.66 & 66.99 & 32.34 & 1.72 & T \\
\hline $3 \mathrm{H}-3,124-126$ & 0.06 & 17.03 & 82.91 & 5.28 & $\mathrm{~T}$ \\
\hline $3 \mathrm{H}-4,44-46$ & 0.48 & 66.84 & 32.68 & 1.77 & T \\
\hline $3 \mathrm{H}-5,44-46$ & 0.24 & 76.56 & 23.19 & 2.23 & $\mathrm{~T}$ \\
\hline $3 \mathrm{H}-5,45-47$ & 0.97 & 76.34 & 22.70 & 2.20 & $\mathrm{~T}$ \\
\hline $3 \mathrm{H}-5,49-51$ & 0.00 & 37.57 & 62.43 & 2.11 & $\mathrm{~T}$ \\
\hline $3 \mathrm{H}-5,128-130$ & 0.24 & 58.12 & 41.64 & 2.17 & P \\
\hline $3 \mathrm{H}-6,59-61$ & 0.84 & 85.11 & 14.05 & 2.93 & T \\
\hline $3 \mathrm{H}-6,128-130$ & 1.15 & 84.52 & 14.33 & 2.92 & $\mathrm{~T}$ \\
\hline $3 \mathrm{H}-7,28-30$ & 0.42 & 87.52 & 12.06 & 3.45 & $\mathrm{~T}$ \\
\hline $4 \mathrm{H}-2,44-46$ & 0.24 & 53.94 & 45.82 & 2.15 & P \\
\hline $4 \mathrm{H}-2,128-130$ & 0.24 & 63.99 & 35.77 & 2.14 & P \\
\hline $4 \mathrm{H}-3,44-46$ & 0.42 & 62.44 & 37.14 & 2.19 & P \\
\hline $4 \mathrm{H}-3,128-130$ & 0.18 & 54.73 & 45.09 & 2.28 & P \\
\hline $4 \mathrm{H}-4,44-46$ & 1.62 & 66.57 & 31.80 & 1.81 & T \\
\hline $4 \mathrm{H}-4,128-130$ & 0.78 & 80.40 & 18.82 & 2.46 & $\mathrm{~T}$ \\
\hline $4 \mathrm{H}-5,44-46$ & 0.48 & 51.19 & 48.33 & 2.21 & $\mathbf{P}$ \\
\hline $4 \mathrm{H}-5,51-53$ & 0.54 & 48.91 & 50.55 & 2.44 & $\mathrm{P}$ \\
\hline $4 \mathrm{H}-5,56-58$ & 0.18 & 57.31 & 42.51 & 2.13 & P \\
\hline $4 \mathrm{H}-5,128-130$ & 0.18 & 55.06 & 44.76 & 2.19 & $P$ \\
\hline $4 \mathrm{H}-6,44-46$ & 0.48 & 55.35 & 44.17 & 2.15 & P \\
\hline $4 \mathrm{H}-6,128-130$ & 0.18 & 60.30 & 39.52 & 2.11 & P \\
\hline $4 \mathrm{H}-7,44-46$ & 0.18 & 65.62 & 34.20 & 2.12 & P \\
\hline $5 \mathrm{H}-4,44-46$ & 0.73 & 76.31 & 22.96 & 2.34 & $\mathrm{~T}$ \\
\hline $5 \mathrm{H}-4,50-52$ & 0.42 & 59.37 & 40.21 & 2.07 & P \\
\hline
\end{tabular}

Note: Depositional modes are $\mathrm{P}=$ pelagic and $\mathrm{T}=$ turbidite. 